\title{
Monitoring Vegetation Dynamics at a Tidal Marsh Restoration Site: Integrating Field Methods, Remote Sensing and Modeling
}

\author{
Alexandra S. Thomsen ${ }^{1}$. Johannes Krause ${ }^{2}$ Monica Appiano ${ }^{3} \cdot K$ Karen E. Tanner ${ }^{4}$. Charlie Endris ${ }^{3}$. John Haskins ${ }^{5}$. \\ Elizabeth Watson ${ }^{2}$. Andrea Woolfolk ${ }^{5}$ - Monique C. Fountain ${ }^{5} \cdot$ Kerstin Wasson $^{4,5}$ (D)
}

Received: 27 October 2020 / Revised: 14 June 2021 / Accepted: 16 June 2021 / Published online: 11 August 2021

(C) The Author(s) 2021

\begin{abstract}
Sea level rise threatens coastal wetlands worldwide, and restoration projects are implementing strategies that decrease vulnerability to this threat. Vegetation monitoring at sites employing new restoration strategies and determination of appropriate monitoring techniques improve understanding of factors leading to restoration success. In Central California, soil addition raised a degraded marsh plain to a high elevation expected to be resilient to sea level rise over the next century. We monitored plant survival and recruitment using area searches, transect surveys, and unoccupied aircraft systems (UAS) imagery. We used random forest modeling to examine the influence of nine environmental variables on vegetation colonization and conducted targeted soil sampling to examine additional factors contributing to vegetation patterns. Limited pre-construction vegetation survived soil addition, likely due to the sediment thickness $($ mean $=69 \mathrm{~cm})$ and placement method. After 1 year, about $10 \%$ of the initially bare area saw vegetation reestablishment. Elevation and inundation frequency were particularly critical to understanding restoration success, with greatest vegetation cover in high-elevation areas tidally inundated $<0.85 \%$ of the time. Soil analysis suggested greater salinity stress and ammonium levels in poorly-vegetated compared to well-vegetated areas at the same elevation. We found that both transect and UAS methods were suitable for monitoring vegetation colonization. Field transects may provide the best approach for tracking early vegetation colonization at moderate-sized sites under resource limitations, but UAS provide a complementary landscape perspective. Beyond elucidating patterns and drivers of marsh dynamics at a newly restored site, our investigation informs monitoring of marsh restoration projects globally.
\end{abstract}

Keywords Salt marsh $\cdot$ Salicornia $\cdot$ Elevation $\cdot$ Salinity $\cdot$ Unoccupied aircraft systems

\section{Introduction}

Communicated by Charles T. Roman

Kerstin Wasson

kerstin.wasson@gmail.com

1 California State University Monterey Bay, 100 Campus Center, Seaside, CA 93955, USA

2 Academy of Natural Sciences of Drexel University, 1900 Benjamin Franklin Pkwy, Philadelphia, PA 19103, USA

3 Moss Landing Marine Laboratories, 8272 Moss Landing Rd, Moss Landing, CA 95039, USA

4 University of California, 1156 High St, Santa Cruz, CA 95064, USA

5 Elkhorn Slough National Estuarine Research Reserve, 1700 Elkhorn Rd, Watsonville, CA 95076, USA
Salt marshes and other wetlands provide numerous benefits to wildlife and humans (Barbier et al. 2011; Mitsch et al. 2015), yet over 50\% of global wetland area has been lost in the past century and future losses are anticipated due to threats such as sea level rise, diminished sediment inputs, and eutrophication (Deegan et al. 2012; Kirwan and Megonigal 2013; Weston 2014; Watson et al. 2017; Li et al. 2018). Many human benefits are lost as marsh area declines, including buffering from flooding, biodiversity support for fisheries and tourism, and carbon sequestration (Barbier et al. 2011). In order to reverse the historical trend of marsh loss and maintain the value of these areas for their ecosystem functions and services, the number and scale of restoration projects has been increasing in recent decades, and new techniques are being tested (Callaway et al. 2011; Li et al. 2018). 
Marshes occupy a narrow vertical range in the intertidal zone, between mean sea level and the king tide line, with most plant species occurring above mean high water (Larson 2001). Reduced riverine sediment supplies and subsidence due to groundwater overdraft or diking have resulted in marsh plain elevation loss relative to sea level (Kennish 2001). In combination with these other impacts, accelerating sea level rise further decreases the relative elevation of marshes, making them vulnerable to drowning (Kirwan and Megonigal 2013). Sediment placement on degrading marshes is a restoration technique intended to build the "elevation capital" of marshes to increase their resilience to sea level rise (Mendelssohn and Kuhn 2003; Cahoon et al. 2019). These projects have typically used applications of sediment that allow for survival and vertical growth of marsh vegetation through the added sediment, with natural seedling recruitment supplementing growth of surviving vegetation to restore marsh cover (Raposa et al. 2020). Thick sediment applications on highly degraded and subsided marshes, which likely rely more on colonization by tidally dispersed seeds than on vegetation survival (Mendelssohn and Kuhn 2003), require further study to better understand redevelopment of vegetation cover.

Monitoring of restoration sites is essential to improve understanding of the criteria that make marsh restoration successful and inform planning for future projects (Williams and Faber 2001). Vegetation cover is typically used as at least one metric for monitoring restoration progress, as this represents establishment of the foundation species that other marsh species depend on. Innovative methods, such as using imagery collected by unoccupied aircraft systems (UAS), are also being examined to help researchers keep up with an increasing scale and frequency of restoration projects with limited monitoring budgets and staff (Shuman and Ambrose 2003). Remote sensing methods like UAS may be advantageous over traditional field survey methods, like transect sampling, because they can cover large areas in a short period of time while minimizing trampling of newly established vegetation and disturbance to wildlife (Shuman and Ambrose 2003; Tuxen et al. 2008; Chabot and Bird 2015). While UAS monitoring of revegetation associated with restoration projects is an emerging trend (Knoth et al. 2013; Buters et al. 2019; Haskins et al. 2021), its utility in monitoring and understanding early vegetation colonization at restoration sites requires further study. UAS methods have not been extensively applied to mapping and modeling very early vegetation colonization in wetlands, likely because the ultra-high-resolution imagery necessary to identify small patches of plants has only recently become widely available (Anderson and Gaston 2013; Gray et al. 2018).

Many factors can influence marsh vegetation distribution by influencing (1) tidally dispersed seed delivery and (2) seed germination and seedling survival. Seed delivery in coastal marshes is mainly influenced by the tides, which transport seeds from nearby established marshes in the water and attached to wrack (Huiskes et al. 1995; Armitage et al. 2006; Morzaria-Luna and Zedler 2007). Tidal inundation also influences abiotic conditions that can promote or inhibit germination and growth, including moisture and salinity (Mahall and Park 1976c; Shumway and Bertness 1992; Noe and Zedler 2000, 2001; Woo and Takekawa 2012). Tidal creeks influence marsh species distributions (Zedler et al. 1999; Sanderson et al. 2001) and vegetation height and biomass (Schile et al. 2011), with possible mechanisms including improved drainage near creeks and flushing of salts and other toxins. Additional factors related to soil addition, such as the properties (Reimold et al. 1978; Wigand et al. 2016) and thickness (Stagg and Mendelssohn 2010; Walters and Kirwan 2016) of added soil, can also affect marsh plant survival and colonization.

Recently, a major project was undertaken in Elkhorn Slough, an estuary in Central California, to restore a formerly diked and degraded salt marsh using substantial soil addition to create a high-elevation marsh plain. Limited marsh vegetation (less than $20 \%$ cover) was present before construction of the restoration site, and one area of interest was whether some of it would survive soil addition. However, the major focus was on examining new colonization via seeds. The unusually high elevation of the new site (mostly above mean higher high water) made expectations for natural colonization uncertain. How quickly would the site be colonized by new plants? Would any species other than the marsh dominant, Salicornia pacifica (perennial pickleweed), colonize the site? What factors are associated with natural colonization? The initially bare state and lack of seed bank at this site provide a unique opportunity to study these questions. We used a combination of data collected through area searches, transect-based field surveys, UAS monitoring, and targeted soil sampling to assess restoration progress and evaluate the potential factors influencing early marsh vegetation colonization. We expected that vegetation development would depend on factors related to elevation and inundation, tidal creek influence, the soil addition process, and soil properties. Overall, improving understanding of the vegetation colonization process will inform managers about the most important factors to consider when designing high marsh restoration projects, and comparing field- and UAS-based monitoring methods will reveal relative benefits of different strategies to inform future monitoring and analysis.

\section{Methods}

\section{Site Description}

We conducted this research at a recently restored 25-ha marsh in Elkhorn Slough, located in Monterey Bay in Central 
California (Fig. 1). Marsh vegetation in the Slough supports hundreds of species of wildlife, stores carbon, and filters water, yet many of these valuable marshes have been converted for agriculture or other development. Historical marsh loss in Elkhorn Slough has paralleled the global decline, with approximately $50 \%$ of vegetated marsh area lost in the past 150 years (Van Dyke and Wasson 2005). Much of the remaining vegetated marsh area may drown due to sea level rise in the next century (Wasson et al. 2012). The threat of sea level rise is exacerbated by other stressors including high erosion rates associated with engineering of the estuary mouth, low sediment supply due to river diversion, and eutrophication (Wasson et al. 2017).

Elkhorn Slough is a heavily marine-influenced estuary, with strong tidal currents and most of its waters near marine salinity (Caffrey et al. 2002). Marsh vegetation in this region typically grows through the spring and summer (Mahall and Park 1976a), with natural dieback in the fall and winter. Seeds of the most common marsh plants in Elkhorn Slough are dispersed in the winter and typically begin germinating in the early spring (Mayer 1987).

An ecosystem-based management initiative launched by the Elkhorn Slough National Estuarine Research Reserve (ESNERR) resulted in 25 ha of restored marsh area, known as Hester Marsh, in 2018. This area included 19 ha of degraded marsh that had been diked and drained, then subsided and degraded to mudflat once the dikes failed. The restoration area also included 6 ha of former agricultural land that was graded to facilitate upland migration in response to anticipated sea level rise. Between December 2017 and August $2018,176,000 \mathrm{~m}^{3}$ of soil and sediment were used to restore the degraded marsh plain, raising it by an average of $69 \mathrm{~cm}$ to a target elevation of $1.89 \mathrm{~m}$ NAVD88 (inundated $1-2 \%$ of the time), an elevation expected to be resilient to sea level rise for at least 100 years. Tidal creeks were excavated following soil and sediment addition to resemble the historical creek network. The material added to the degraded marsh was primarily upland soil from former farmland on an adjacent hillside combined with some dredge material from the Pajaro River Bench Excavation Project (Fountain et al. 2019). We will refer to the combined upland and dredge material as "soil" throughout this paper. Because of variation in elevation across the landscape prior to restoration (e.g., high berms, low mudflats, and basins) the amount of soil addition varied across the site, and some high areas had soil removed ("scraped"), rather than added, to meet the target marsh elevation. Placement of soil from these sources resulted in a new high intertidal plain that was virtually bare and lacked halophyte seeds when it was opened to tidal exchange in August 2018. Six blocks were actively planted on the western side of the site, and were excluded from analyses of natural colonization (Fig. 1).

We considered the Hester Marsh restoration project footprint (Fig. 1) to be the area below an elevation of $2.3 \mathrm{~m}$ NAVD88 in August 2018 according to a UAS-derived digital surface model (DSM). This includes the construction zone where soil addition or removal occurred, in addition to a very narrow band of existing marsh vegetation on the eastern and southern restoration site edges that was neither buried nor scraped. While DSMs measure the elevation of the surface and any features on it, we primarily relied on DSMs collected when the site was mostly bare so the models would

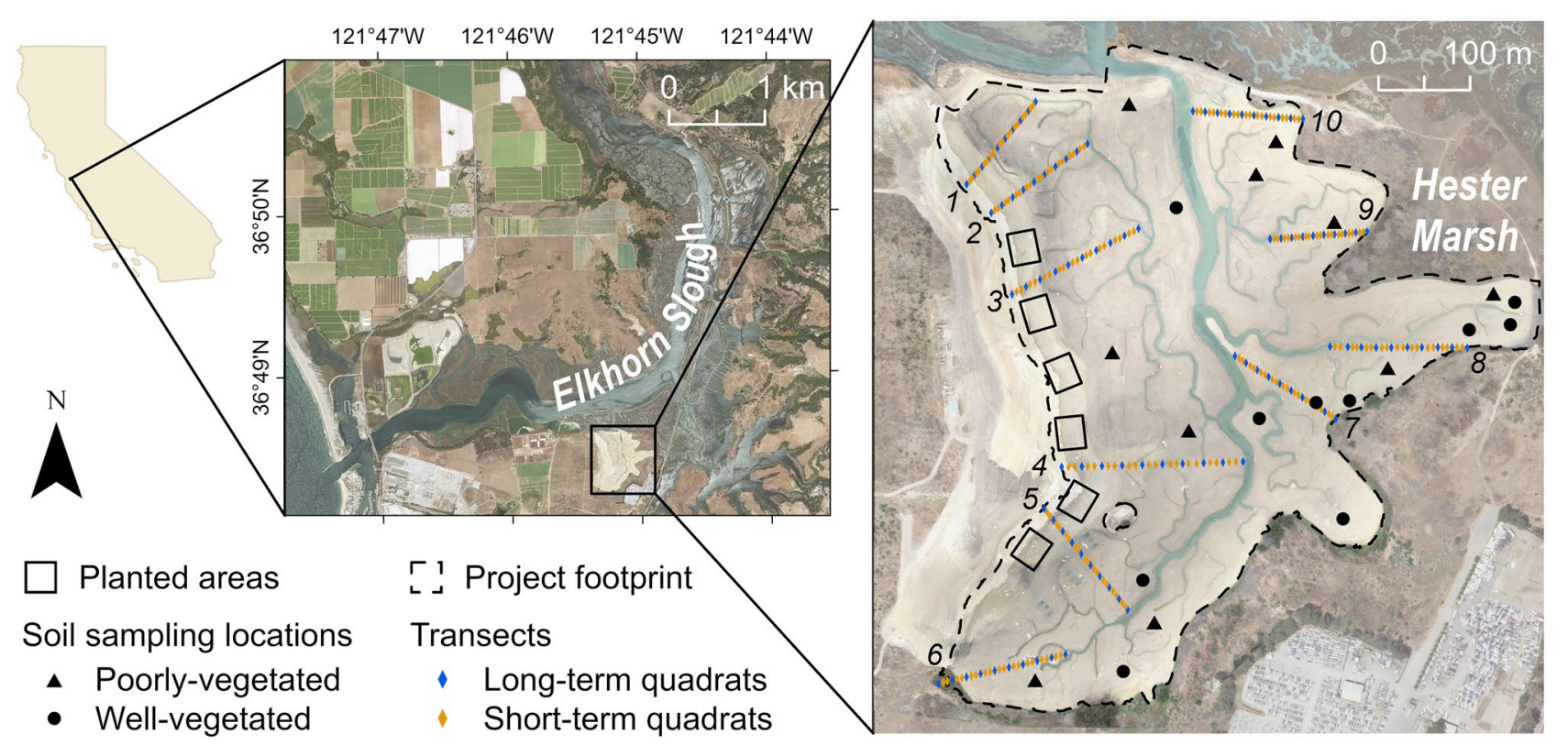

Fig. 1 Geographic location and site map of Hester Marsh, located on the southern side of Elkhorn Slough in Central California, USA 
better approximate bare earth. However, we recognize that elevations in areas of our DSMs with larger, well-established plants may not be accurate.

\section{Estimating Vegetated Area Before Degradation and Before Restoration}

To quantify baseline conditions at the focal marsh prior to anthropogenic activities that led to marsh degradation (primarily through diking and draining), we digitized historical vegetated area using earliest available aerial imagery from 1931. To quantify vegetated area under degraded conditions shortly prior to initiation of the restoration project, we used 2015 UAS imagery (Electronic Supplement 1).

\section{Area Searches for Marsh Vegetation Surviving Construction}

To examine plant survival following the construction phase of restoration, we conducted area searches of the construction zone in Fall 2018. This method involved walking the entire construction zone where soil was added or removed in an attempt to find every plant that survived construction. We logged the locations and approximate numbers of plants we encountered using a handheld GPS (Trimble Juno 3B, Trimble Inc., Sunnyvale, CA). We quantified the area covered by surviving plants based on the number of plants of each species logged with the GPS and an approximate size of an individual of each species. To better understand the spatial patterns of vegetation survival, we examined the GPS points in relation to digitized 2015 UAS imagery (Electronic Supplement 1). To quantify the existing marsh vegetation outside the construction area that remained on the restoration site edge, we digitized this area from UAS imagery collected in August 2018. We estimated the total vegetated marsh area in 2018 as the sum of surviving vegetation cover and the digitized existing vegetation.

\section{Transect Monitoring of Vegetation Colonization}

We monitored vegetation, elevation, and associated parameters over time along 10 permanent transects established by ESNERR (Fig. 1). Using a systematic approach, transects were spread fairly evenly across the restoration footprint, though they were limited to areas that could be traversed on foot without crossing tidal creeks. Transect length ranged from 117 to $198 \mathrm{~m}$. Each transect had 10 quadrats spread uniformly from the seaward marsh boundary at the edge of a tidal creek to the landward marsh boundary approximately at king tide elevation. These 100 quadrat locations were marked with PVC or conduit pipe as fixed points at which ESNERR will track long-term changes for the next several decades. The landward end of five of the transects (transects 6-10 in Fig. 1) started in existing marsh vegetation that was not scraped or buried during construction. Quadrats in existing vegetation were excluded from summary graphs.

This research examines the first 12 months of data collected approximately quarterly at these transects (August 2018, October 2018, April 2019, August 2019). Because cover of new plants was initially so low, we added two evenly spaced temporary quadrats between each of the long-term ones, resulting in 28 quadrats per transect (280 total quadrats) monitored in April and August 2019. We monitored vegetation cover at all quadrats. For the longterm quadrats, we also measured maximum canopy height of Salicornia (the dominant vegetation).

We measured vegetation cover at each quadrat using the point-intercept method within a $50 \mathrm{~cm}$ by $50 \mathrm{~cm}$ PVC frame. At each of the 16 intercepts on a string grid within the frame, we dropped a metal rod and recorded the presence of each plant species that touched the rod (or "bare" if no live plants were encountered). We used the intercept data to calculate percent cover for each species within the quadrat (Electronic Supplement 1). We collected maximum canopy height data for Salicornia in each quadrat by measuring the tallest stem within a $10-\mathrm{cm}$ radius at each of three marked intercepts. We estimated relative Salicornia biomass for each quadrat by multiplying the average of the three canopy heights by percent cover of Salicornia.

To monitor elevation, we established baseline conditions in August 2018 at the 100 long-term quadrats using RTK GPS (EOS Arrow 200 with ArcGIS Collector) and monitored elevation in August 2019 at all 280 long-term and temporary quadrats using a Sprinter 150 laser level. All elevations are reported in meters referenced to the North American Vertical Datum of 1988 (NAVD88). We calculated salinity based on apparent conductivity measurements at all 280 long-term and temporary quadrats at the end of the dry season in September 2019. We collected field measurements of apparent conductivity using a Geonics Model EM38 MK2 Conductivity Meter (Geonics Ltd., Mississauga, Ontario, Canada) and recorded the readings on a handheld GPS (Garmin GPSMAP 64ST, Garmin Ltd., Olathe, KS). We used a calibration function derived from 22 soil samples collected at the time of the conductivity survey to model salinity at each quadrat based on apparent conductivity (a subset of the points shown in Electronic Supplement 1, Fig. S5; Krause 2020).

We examined nine potential factors influencing native marsh vegetation cover during the first growing season using August 2019 transect data (Table 1). Values for these predictors were derived from field and UAS surveys, including DSMs and imagery. To include inundation time as a predictor, we calculated percent time inundated over the first year of restoration using data from a nearby water quality monitoring sonde located at Vierra Marsh (Electronic Supplement 1, 
Characterization of Inundation Across Elevations). We used random forest modeling to examine these variables due to the strength of this regression tree method in modeling many different predictors and complex, nonlinear relationships (Cutler et al. 2007). We performed modeling using the randomForest package (v. 4.6-14; Liaw and Wiener 2002) in R software (v. 3.5.1; R Core Team 2018; number of trees $=1500$, apply correction bias, other parameters left at defaults). We systematically removed one variable at a time to determine which factors to include in the final model (Electronic Supplement 1). We report the importance of individual variables in the final vegetation cover model as the percentage increase in mean squared error (MSE), which represents reduction in model performance, when the values of the predictor are randomly permuted (Cutler et al. 2007).

\section{Site-Wide UAS Monitoring of Vegetation Colonization}

We monitored vegetation development and elevation changes for the first year of restoration approximately monthly using UAS imagery. We analyzed factors influencing vegetation presence based on high-resolution imagery collected in October 2019 (pixel size $=0.79 \mathrm{~cm}$; Electronic Supplement 1 ), at the end of the first growing season. We created a classified image of vegetated and unvegetated areas using the October imagery in ArcGIS software (v. 10.7, ESRI 2019) and used this classified image to determine total vegetated area in 2019 and percent vegetation cover in $1-\mathrm{m}^{2}$ cells. Initially, we created two classified images using a pixel-based and an object-based approach, and selected the more accurate of the two classified images based on qualitative and quantitative assessment. We used stratified random sampling to sample 150 low-cover and 150 high-cover cells for sitewide modeling of factors influencing vegetation cover (Electronic Supplement 1, Site-Wide UAS Monitoring of Vegetation Colonization). We used tide data from a nearby sonde to limit our analysis to the extent of expected marsh plant seed dispersal, in order to exclude most upland plant cover (Electronic Supplement 1, Characterization of Inundation Across Elevations).

Several UAS DSMs and DSM-derived products were used as potential predictors of vegetation development in site-wide vegetation cover analysis, in addition to other GISderived predictors (Table 1). In order to include salinity as one of the nine predictors, we modeled salinity across the site based on September 2019 field measurements of conductivity at 349 points using a machine learning approach with elevation, amount of soil addition/removal, and tidal creek distance as predictors using Forest-Based Regression in ArcGIS Pro (number of trees $=1500$, replicates $=15$, data withheld for validation per replicate $=25 \%$ ). We evaluated the influence of the nine potential predictors on vegetation cover using random forest modeling with the randomForest package (v. 4.6-14; Liaw and Wiener 2002) in R software (v. 3.5.1; R Core Team 2018). We used the same parameters and technique for variable selection and performance assessment that we used for modeling the transect data.

\section{Soil Comparison at Well-Vegetated and Poorly-Vegetated Sites}

We collected soil samples at 10 well-vegetated and 10 poorly-vegetated sites of similar elevation and distance to tidal creeks to examine additional factors that might be leading to low colonization and growth in some areas but were

Table 1 Predictors examined in transect and site-wide UAS analyses of vegetation cover

\begin{tabular}{|c|c|c|}
\hline Variable & Source for transect analysis & Source for site-wide UAS analysis \\
\hline Elevation post-restoration $(\mathrm{m})$ & Measured using laser leveling in August 2019 & August 2018 DSM (pixel size $=3.3 \mathrm{~cm}$ ) \\
\hline Inundation (\% time) & $\begin{array}{l}\text { Calculated using ESNERR Vierra Marsh tide data } \\
\text { (Aug 2018-May 2019) and field-measured eleva- } \\
\text { tion }\end{array}$ & $\begin{array}{l}\text { Calculated using ESNERR Vierra Marsh tide data } \\
\text { (Aug 2018-May 2019) and May } 2019 \text { DSM (pixel } \\
\text { size }=3.3 \mathrm{~cm} \text { ) }\end{array}$ \\
\hline $\begin{array}{l}\text { Elevation change over first year of } \\
\text { restoration }(\mathrm{m})\end{array}$ & $\begin{array}{l}\text { Calculated by subtracting August } 2018 \text { DSM from } \\
\text { May } 2019 \text { DSM (pixel size }=3.3 \mathrm{~cm} \text { ) }\end{array}$ & $\begin{array}{l}\text { Calculated by subtracting August } 2018 \text { DSM from } \\
\text { May } 2019 \text { DSM (pixel size }=3.3 \mathrm{~cm} \text { ) }\end{array}$ \\
\hline Salinity (ppm) & $\begin{array}{l}\text { Calibrated from apparent conductivity readings and } \\
\text { soil samples (Sept 2019) }\end{array}$ & $\begin{array}{l}\text { Modeled using Forest-Based Regression in ArcGIS } \\
\quad \text { (pixel size }=3.3 \mathrm{~cm} \text { ) }\end{array}$ \\
\hline Creek distance $(\mathrm{m})$ & $\begin{array}{l}\text { Calculated using Euclidean Distance from polygon } \\
\text { feature }\end{array}$ & $\begin{array}{l}\text { Calculated using Euclidean Distance from polygon } \\
\text { feature (pixel size }=25 \mathrm{~cm} \text { ) }\end{array}$ \\
\hline Soil source (categorical) & $\begin{array}{l}\text { Digitized from mid-construction UAS imagery (Feb } \\
\text { 2018) }\end{array}$ & $\begin{array}{l}\text { Digitized from mid-construction UAS imagery (Feb } \\
\text { 2018) }\end{array}$ \\
\hline Soil addition/removal (categorical) & $\begin{array}{l}\text { Categorical elevation change raster (Oct } 2015 \text { DSM } \\
\text { subtracted from Aug } 2018 \text { DSM; pixel size }=6 \mathrm{~cm} \text { ) }\end{array}$ & $\begin{array}{l}\text { Categorical elevation change raster (Oct } 2015 \text { DSM } \\
\text { subtracted from Aug } 2018 \text { DSM; pixel size }=6 \mathrm{~cm} \text { ) }\end{array}$ \\
\hline Elevation pre-restoration (m) & Oct 2015 DSM $($ pixel size $=6 \mathrm{~cm})$ & Oct 2015 DSM (pixel size $=6 \mathrm{~cm}$ ) \\
\hline Former habitat type (categorical) & Digitized 2015 habitat map & Digitized 2015 habitat map \\
\hline
\end{tabular}


not represented in transect or UAS surveys (Fig. 1). Wellvegetated areas were those with relatively high cover and large plants, while poorly-vegetated areas were those with low cover and small plants. We identified sampling locations using UAS imagery and a DSM (Electronic Supplement 1).

We located these sites in the field with a handheld GPS (Trimble Juno 3B, Trimble Inc., Sunnyvale, CA) and collected two samples at each site under clear conditions on October 2, 2019. We analyzed one set of samples for six soil properties and sent another set of samples to a third-party soil testing facility for analysis of additional properties (Control Laboratories, Watsonville, CA). We collected all samples at least $20 \mathrm{~cm}$ from plants. We also measured the height of the tallest five plants within a 1-m radius of the GPS point (or all plants, if there were fewer than five present). We collected 20 samples for soil property analysis with a push corer to an average depth of $18 \mathrm{~cm}$ (SD 3.6) and examined them for mean grain size (bulk and digested), moisture content, carbon content, and Atterberg liquid and plastic limits using standard procedures (Clarke et al. 2014a; National Lacustrine Core Facility 2013; NYDOT 2015). We analyzed 20 additional soil samples $(0-10 \mathrm{~cm})$ by homogenizing three triplicate samples collected $0.3 \mathrm{~m}$ apart for nitrate, ammonium, phosphorus, saturation (\%), $\mathrm{pH}$, conductivity, sodium, chloride, sulfate, calcium, potassium, magnesium, and cation exchange capacity (Electronic Supplement 1).

We conducted a suite of related non-metric multidimensional scaling analyses using Primer v. 7.0 to determine whether soil properties differed between well- and poorly-vegetated sites, and which parameters contributed to those differences (Clarke et al. 2014b). Data were normalized to enable comparison between variables with different scales. We created a Euclidean similarity matrix and visualized differences among well- vs. poorlyvegetated sites using a two-dimensional ordination plot and carried out an analysis of similarity (ANOSIM) to test for differences among the categories. We used similarity percentages (SIMPER) to further examine groupings and the variables that best distinguished them. We also conducted $t$ tests to compare categories for the variables that emerged as important in the SIMPER.

\section{Results}

\section{Estimating Vegetated Area Before Degradation and Before Restoration}

Historical vegetated area within the restoration project footprint was approximately 18.5 ha in 1931 (Figs. 2 and $3 a)$. Vegetated area declined to 4.6 ha by 2015 , which is representative of the state of the marsh prior to restoration (Figs. 2 and 3b). Assuming the target restoration goal of a fully vegetated marsh plain is achieved (the entire project footprint excluding creeks is vegetated), there will be more marsh area than there was in 1931 (Fig. 2).

\section{Area Searches for Marsh Vegetation Surviving Construction}

During area searches in Fall 2018, 2 to 3 months after construction ended, we recorded a total estimate of 4142 plants (Fig. 3c). Surviving plants were mostly found on or near berms that had been scraped during restoration site construction (Electronic Supplement 1). These plants were mostly native marsh species (Distichlis spicata, Frankenia salina, Salicornia, Jaumea carnosa, and Spergularia sp.) but included $0.3 \%$ upland non-native species. Based on estimates of plant numbers and assumed sizes of individuals of each species, surviving plant cover was $31 \mathrm{~m}^{2}$ within the construction zone. An additional $2542 \mathrm{~m}^{2}$ of marsh vegetation was present within the project footprint in Fall 2018, corresponding to a relatively narrow strip of existing vegetation on site edges that was not scraped or buried during construction (Fig. 3c). The total vegetated area within the project footprint in 2018 was 0.26 ha (Fig. 2).

\section{Transect Monitoring of Vegetation Colonization}

During the initial transect vegetation surveys in August and October 2018, no live vegetation was found in the long-term monitoring quadrats in the initially bare construction zone;

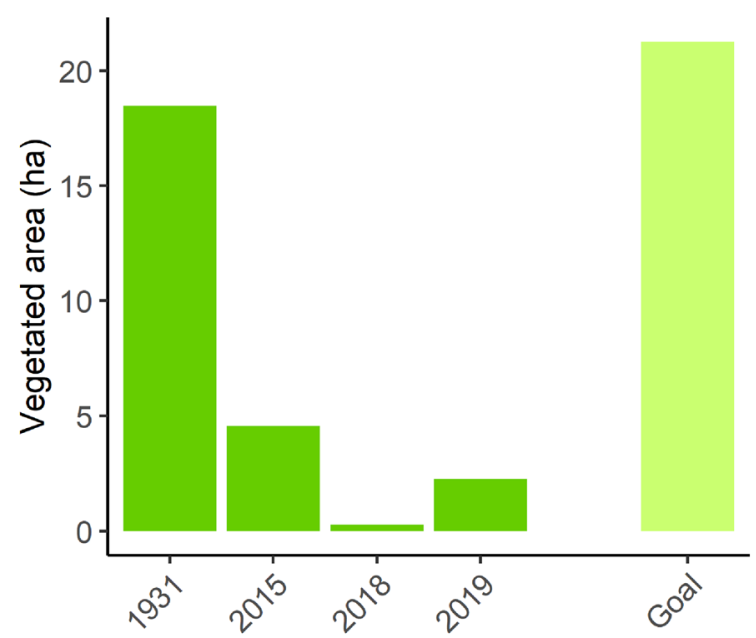

Fig. 2 Vegetated marsh area within Hester Marsh project footprint, 1931-present, and future planned vegetated area. Areas in 1931 and 2015 represent historical and degraded pre-restoration conditions, respectively. Area in 2018 represents vegetation following soil addition, while area in 2019 represents conditions after a growing season of restoration 


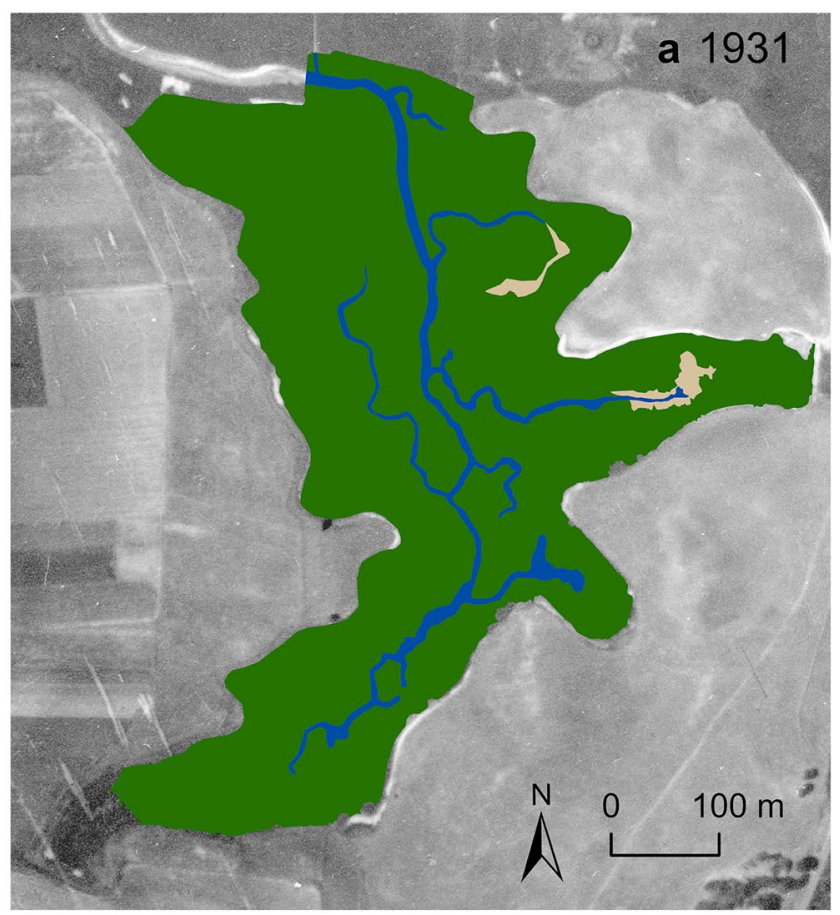

\section{Vegetated marsh $\square$ Creeks Unvegetated mud}

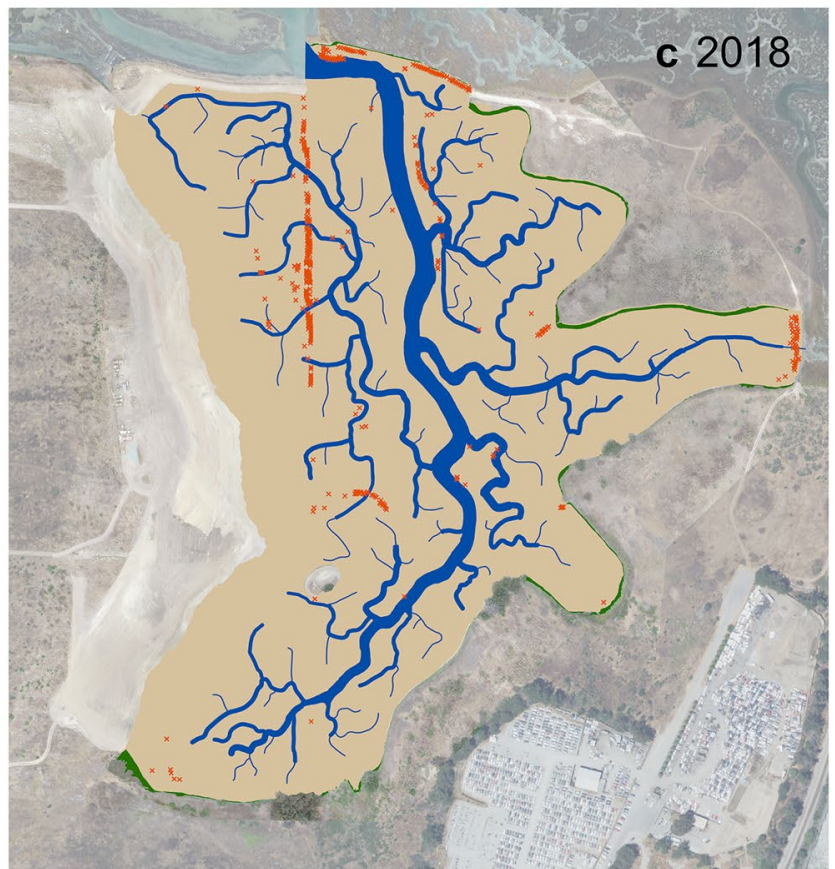

Existing vegetation $\times$ Surviving plants

Fig. 3 Maps of vegetated areas within Hester Marsh, 1931-present. a Digitized 1931 aerial imagery of the historically well-vegetated marsh. b Digitized 2015 UAS imagery of the marsh, which had degraded to mostly unvegetated mudflat before construction of the restoration site. $\mathbf{c}$ The relatively bare landscape at the end of construction in August 2018, with locations of surviving plants logged during

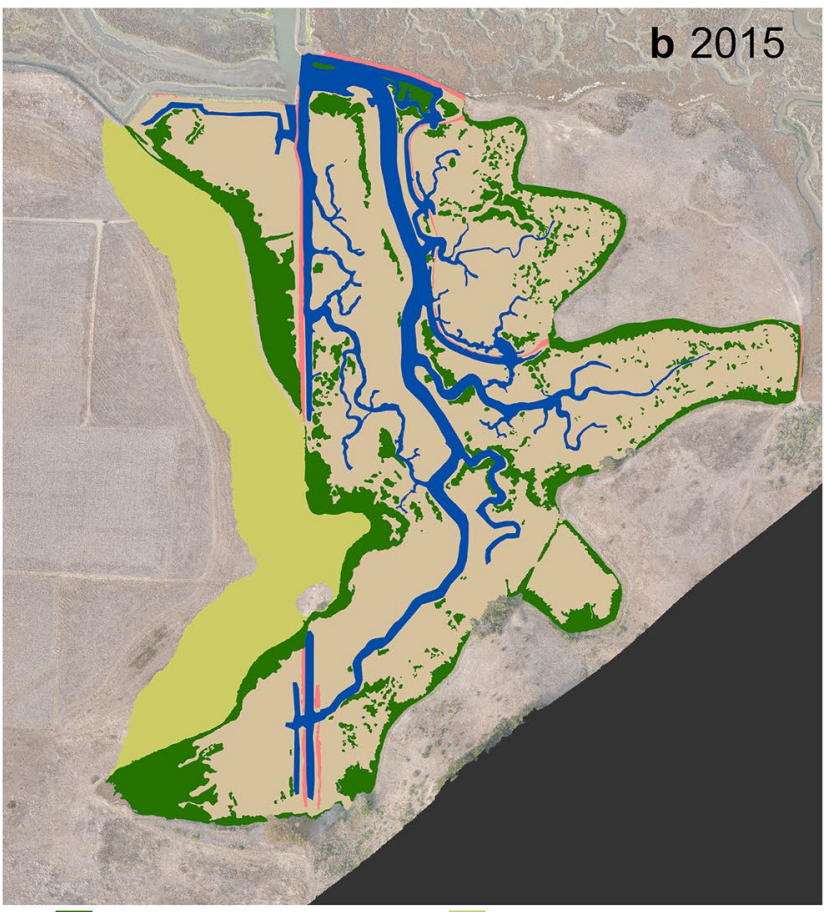

Vegetated marsh Unvegetated mud Creeks

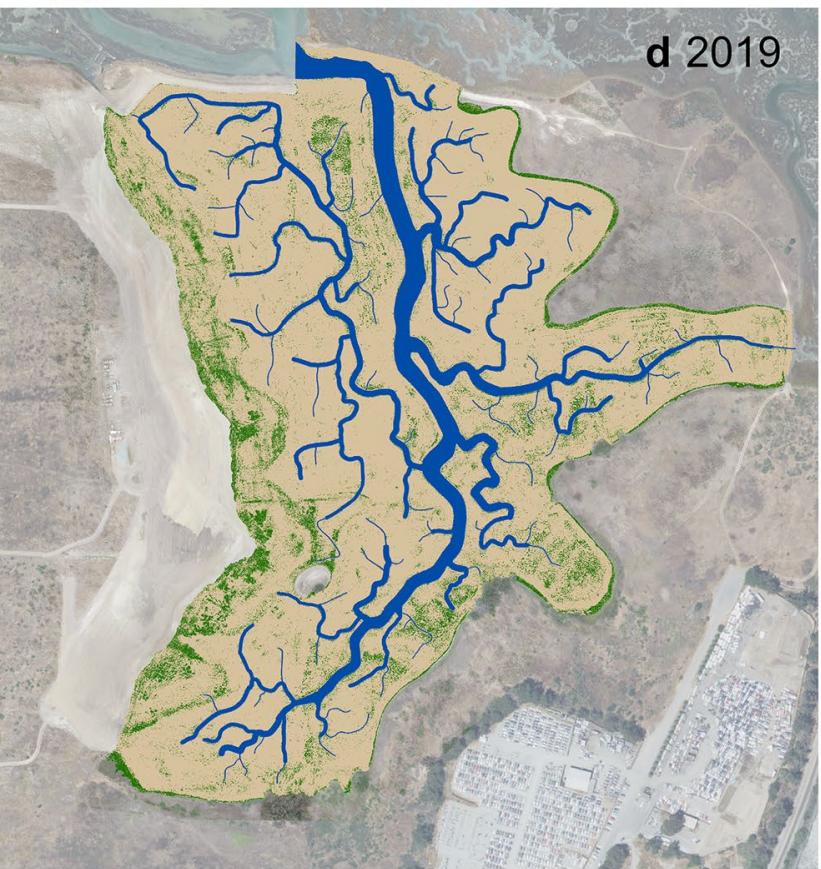

Vegetated marsh

Unvegetated mud

GPS surveys and digitized existing vegetation above the construction area. Points are enlarged to be visible, and cover of surviving vegetation was much less than implied by size of points. d Classified October 2019 UAS imagery showing patchiness of natural vegetation colonization 


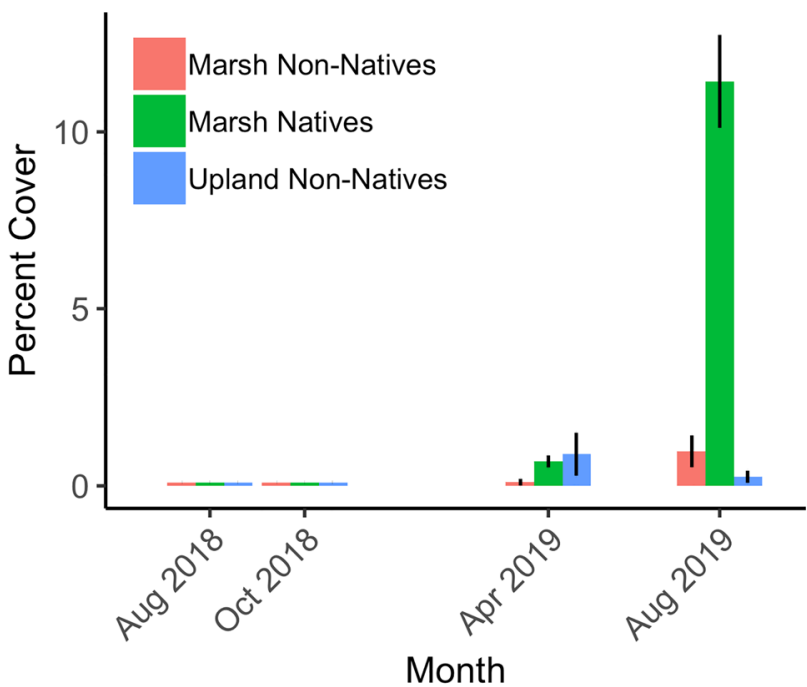

Fig. 4 Marsh native, marsh non-native, and upland non-native cover from quarterly transect surveys, August 2018-August 2019. Data from 2018 were collected only in long-term quadrats $(n=94)$, while 2019 data included long-term and short-term quadrats $(n=269)$. Error bars represent standard error of the mean

existing vegetation at the landward end of eastern and southern transects persisted, with over $100 \%$ plant cover due to canopy layering (consisting of mostly Distichlis, Salicornia, Frankenia, and Jaumea). In April 2019, average cover of all plants combined was still low (2.1\%) in the initially bare construction zone. By August 2019, average cover reached $13.6 \%$ in the construction zone (Fig. 4). New vegetation was dominated by native species, with $11.4 \%$ average native marsh cover ( $99 \%$ of which was Salicornia, with minimal Frankenia and Spergularia cover). Cover of marsh non-natives (Atriplex prostrata and Parapholis incurva) and upland non-natives was $1.0 \%$ and $0.3 \%$, respectively.

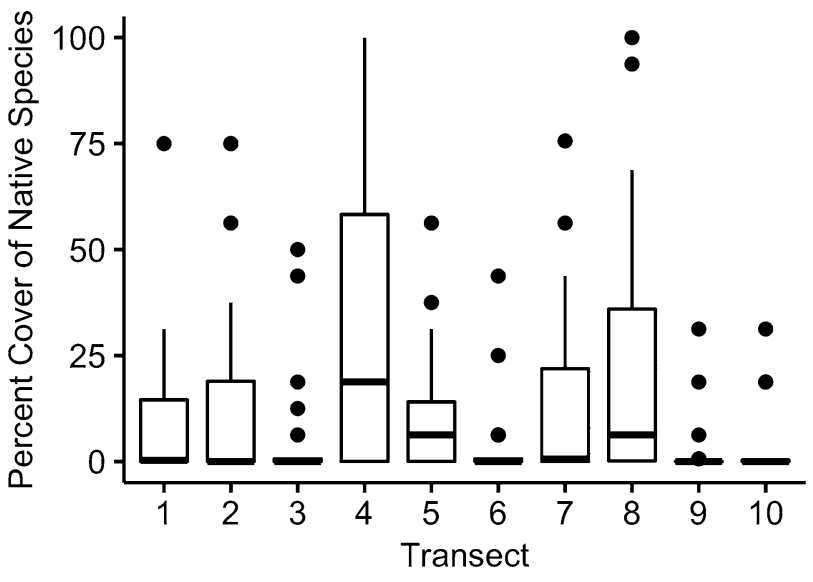

Fig. 5 Percent cover of native marsh plants on 10 transects, August 2019
Additionally, cover of non-native Erigeron bonariensis and native $E$. canadensis combined was $0.9 \%$, but we could not distinguish between the native and non-native during field surveys.

Average maximum canopy height for newly colonized Salicornia in August 2019 was $6.9 \pm 4.6 \mathrm{~cm}$, while it was $35.2 \pm 5.2 \mathrm{~cm}$ in the quadrats with existing vegetation that was present before restoration. Relative biomass calculated from Salicornia height and cover was $300 \pm 486 \mathrm{~cm}^{3}$ in quadrats with new colonization and $3092 \pm 838 \mathrm{~cm}^{3}$ in quadrats with existing vegetation.

Percent cover of native marsh vegetation in the construction zone in August 2019 varied among transects (Fig. 5). On average, quadrats at or above the median elevation of $1.93 \mathrm{~m}$ had significantly greater cover $($ mean $=16.1 \%, n=134)$ than quadrats below median elevation $($ mean $=6.9 \%, n=133$; one-tailed $t$ test, $p<0.001$; Electronic Supplement 1, Fig. S1). Quadrat elevation ranged from 1.71 to $2.30 \mathrm{~m}$.

Modeling of native marsh cover based on August 2019 transect data revealed the following important predictors (importance in parentheses, measured as percentage increase in MSE when the variable is randomly permuted; Electronic Supplement 1, Fig. S2): post-restoration elevation (22.8), pre-restoration elevation (22.0), salinity (18.7), elevation change over the first year of restoration (14.4), habitat type prior to restoration (7.0), soil addition or removal during construction (6.7), distance to nearest tidal creek (4.9), and soil source (3.7). The model with these variables explained $18.5 \%$ of variance in the data.

Post-restoration elevation (2019) was the most important predictor of native marsh vegetation cover, with predicted cover increasing sharply between 1.9 and $2.0 \mathrm{~m}$ (Fig. 6a). Pre-restoration elevation (2015) was the next most important predictor, with greater vegetation cover predicted in formerly high-elevation areas corresponding to the hillside that was scraped during construction (above $2.8 \mathrm{~m}$ ), and lower cover predicted in areas on the former marsh plain (1.2 to $2.7 \mathrm{~m}$; Fig. 6b; Electronic Supplement 1, Fig. S9). Very low areas prior to construction, such as low basins (below $1.1 \mathrm{~m}$ ) were also modeled to have relatively high cover post-construction. Salinity was the next most important predictor, with lowest cover predicted between 37 and 42 ppt (Fig. 6c). Elevation change over the first year of restoration (August 2018 to May 2019) was also important, with more vegetation cover predicted in areas that experienced elevation loss over that time period (though the initial portion of the drastic decline in predicted cover was driven by relatively few data points; Fig. 6d; Electronic Supplement 1, Fig. S13). Areas that experienced slight elevation loss over the first year of restoration tended to be more frequently inundated, more saline, and closer to tidal creeks. Raw data by former habitat type show greatest cover on former grassland $(\mathrm{G})$, followed by former mudflat (M), but the model predicted only slightly greater cover in 


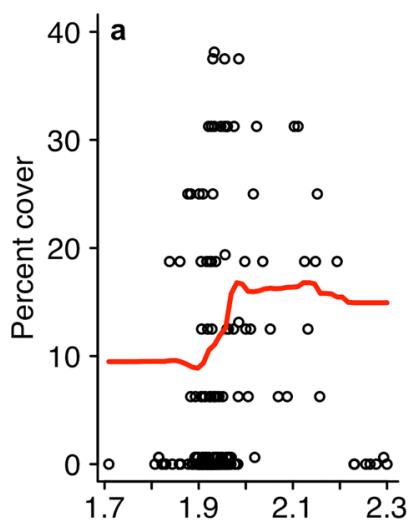

Post-restoration elev. (m)

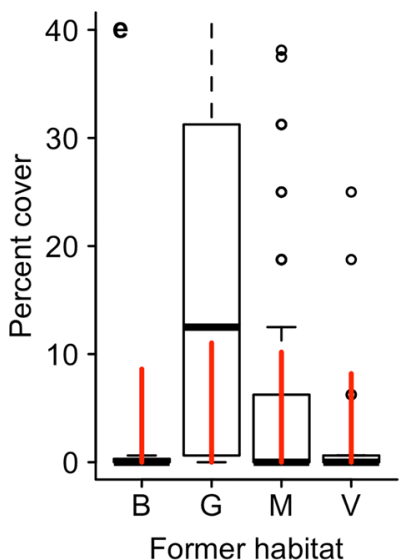

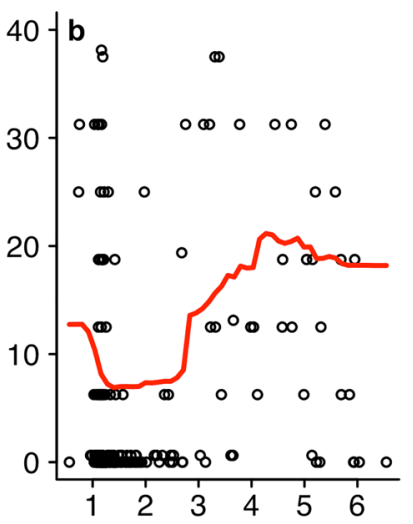

Pre-restoration elev. (m)

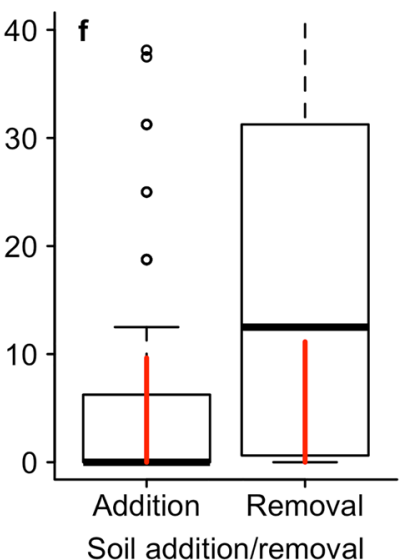

Soil addition/removal

Fig. 6 Partial dependence of transect-surveyed native marsh cover on a post-restoration elevation, $\mathbf{b}$ pre-restoration elevation, $\mathbf{c}$ salinity, d elevation change over the first year of restoration, $\mathbf{e}$ former habitat type $(B=$ vegetated berms, $G=$ grassland, $M=$ mudflats/unvegetated areas, $\mathrm{V}=$ vegetated marsh), $\mathbf{f}$ soil addition or removal, $\mathbf{g}$ creek dis-

these areas (Fig. 6e; Electronic Supplement 1, Fig. S15). Raw data also show greater cover on areas of soil removal, which correspond to the former grassland and berms, but the model predicted only marginally greater cover on those soil removal areas (Fig. 6f; Electronic Supplement 1, Fig. S16). Vegetation cover was found to be greatest both adjacent to $(0-10 \mathrm{~m})$ and far $(<45 \mathrm{~m})$ from tidal creeks (Electronic Supplement 1, Fig. S14), though the latter trend was driven by few data points (Fig. 6g). Vegetation cover was marginally greater on soil sourced from the local hillside compared with Pajaro River sediment (Fig. 6h; Electronic Supplement 1, Fig. S12).

Several of the variables examined in modeling were correlated with each other. Areas that were high in elevation prior to restoration remained at higher elevations postrestoration (Fig. 7a). Soil removal lowered these areas from upland to marsh elevations, but because they are in the transition zone between the marsh plain and upland, they remained relatively high. Salinity was also lowest in these formerly high-elevation, soil removal areas (Fig. 7b).
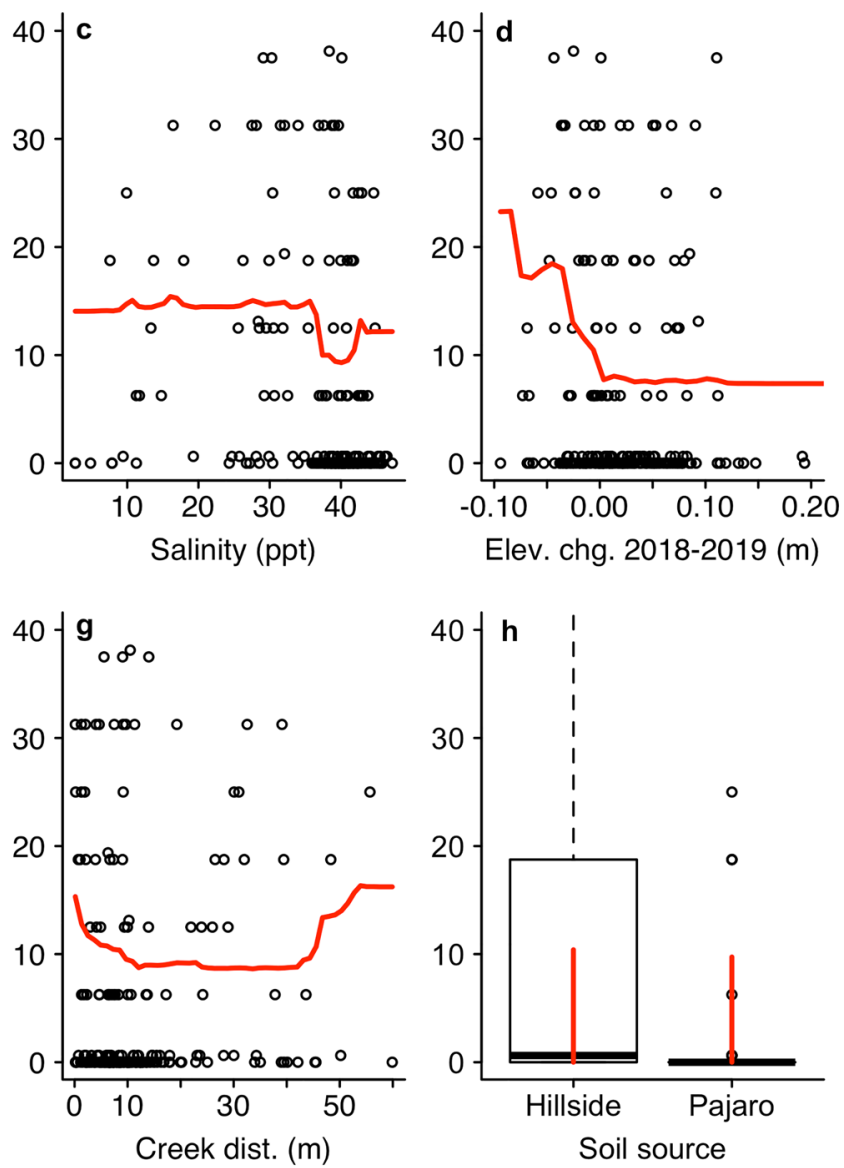

tance, and $\mathbf{h}$ soil source based on random forest modeling. Red lines show model predictions, holding all variables in the model constant except the one plotted. Open circles and boxplots show raw data. Upper $y$-axis limit set at $40 \%$ cover for ease of viewing the majority of data ( 25 high-cover data points not shown)

Salinity and post-restoration elevation were negatively related, with lower salinity in higher-elevation (Fig. 7c), infrequently inundated areas (Electronic Supplement 1, Fig. S3). This trend was mostly driven by the soil removal areas, which tended to have lower salinity for a given elevation (e.g., $1.95 \mathrm{~m}$ ) than soil addition areas. Salinity in the soil addition areas had a weakly negative relationship with elevation, decreasing slightly at elevations above $1.90 \mathrm{~m}$ (Fig. 7c). Inundation time at Hester Marsh ranged from 0.0 to $6.2 \%$ and followed a downward sloping curve in relation to post-restoration elevation, as measured by Vierra Marsh tide data (Fig. 7d).

\section{Site-Wide UAS Monitoring of Vegetation Colonization}

Image classification of high-resolution October 2019 UAS imagery (pixel size $=0.79 \mathrm{~cm}$ ) produced estimates of $2.3 \mathrm{ha}$ of total vegetated cover in the project footprint (the entire 
Fig. 7 Relationships between a post- and pre-restoration elevation, b salinity and prerestoration elevation, $\mathbf{c}$ salinity and post-restoration elevation, and $\mathbf{d}$ inundation time and postrestoration elevation. Data from transect quadrats $(n=252)$
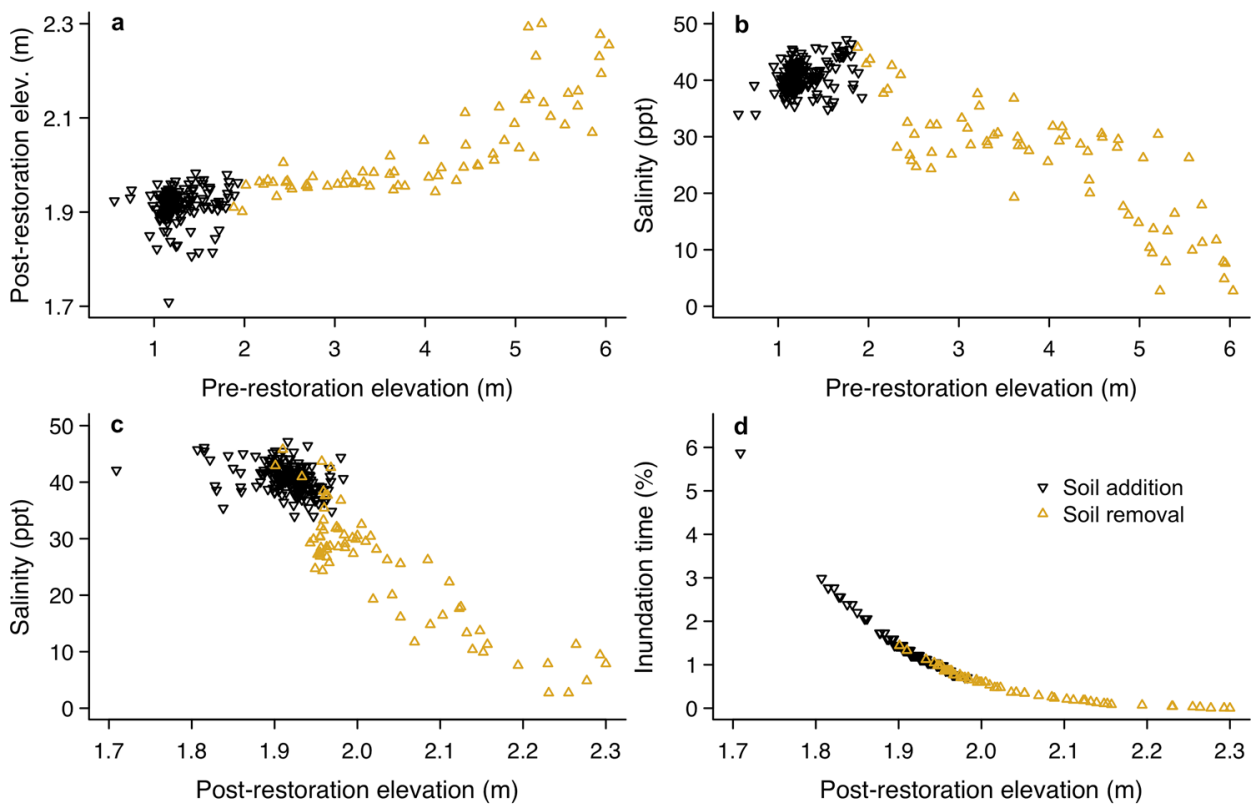

area up to $2.3 \mathrm{~m}$ NAVD88, including soil addition and removal areas as well as existing vegetation that remained above the construction zone; Figs. 2 and $3 \mathrm{~d}$ ). This included 1.4 ha of naturally colonized vegetated cover in the main seed dispersal area (Fig. 8), which we determined was the

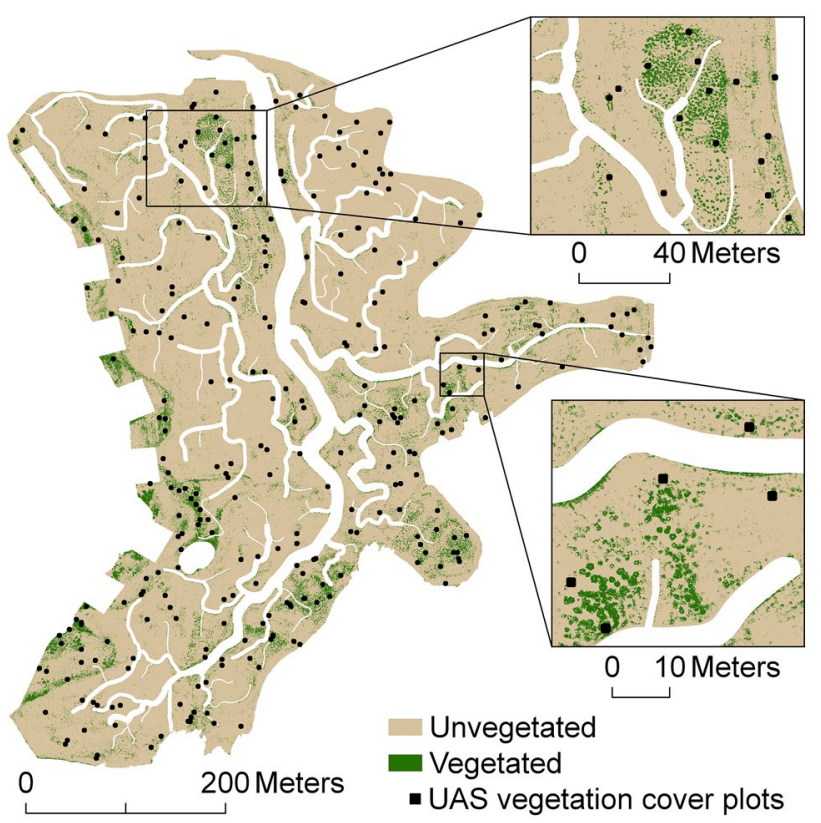

Fig. 8 Classified October 2019 UAS imagery showing vegetated and unvegetated areas and plots for modeling vegetation cover within the main seed dispersal area, excluding actively planted areas and tidal creek interiors. Some example areas are shown to highlight patchiness of natural colonization. We modeled percent cover of classified vegetation in $1-\mathrm{m}^{2}$ plots, created using stratified random sampling in high- and low-cover areas $(n=300)$ area below $2.14 \mathrm{~m}$ (Electronic Supplement 1, Characterization of Inundation Across Elevations). We calculated vegetation cover estimates and performed modeling of vegetation points using the pixel-based classification, because both classified images had good overall accuracy (true skill statistic $=0.82$ and 0.85 for pixel-based and object-based, respectively) but the object-based image had a few relatively large areas that were incorrectly classified. Both methods of classification had additional minor limitations, including difficulty distinguishing sunken footprints and dark mud from vegetation and inability to distinguish different species from each other. These were relatively minor issues in our case, as most vegetation in the main seed dispersal area was Salicornia and problem areas like footprints and dark mud were small relative to the entire area.

Salinity modeling included the following predictors in order of variable importance percentage based on Gini coefficients: amount of soil addition or removal during construction (importance $=41 \%$ ), elevation (importance $=36 \%$; Electronic Supplement 1, Fig. S5), and tidal creek distance (importance $=23 \%$ ). Model validation indicated fairly good performance (out-of-bag root mean square error, RMSE $=3.1 \%$ ). Salinity was predicted to be lowest at high elevations that were inundated infrequently, and salinity was particularly low in the former grassland on the western side of the site that had upper layers of soil removed during the construction process, and which remained at higher elevation than the marsh plain to the east (Fig. 7a-c; Electronic Supplement 1, Fig. S11).

Site-wide modeling of classified vegetation cover in the main seed dispersal area included the following important predictors explaining vegetation cover during the first year 

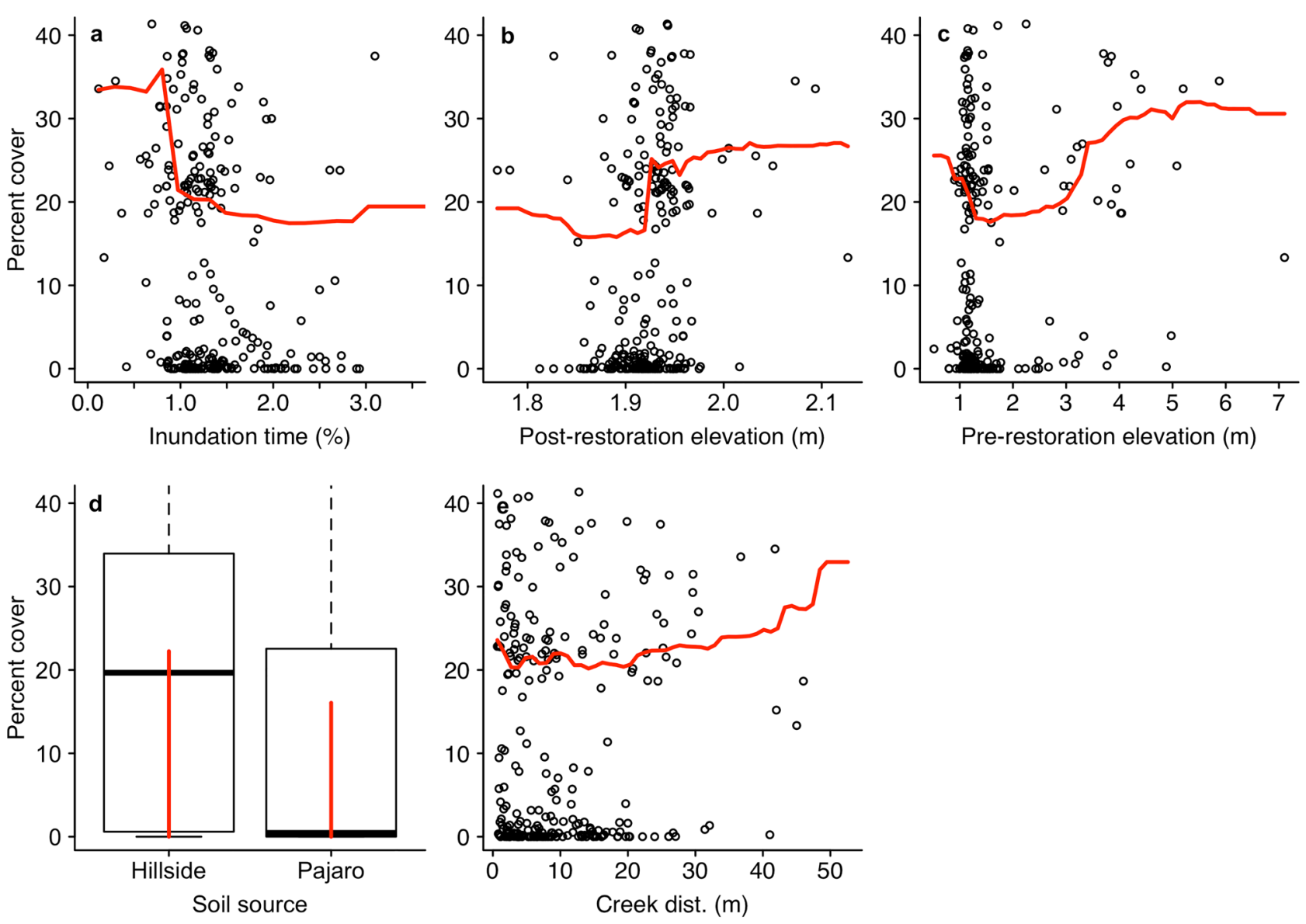

Fig. 9 Partial dependence of UAS-derived vegetation cover on a percent time inundated, b post-restoration elevation, $\mathbf{c}$ pre-restoration elevation, $\mathbf{d}$ soil source, and e creek distance based on random forest modeling. Red lines show model predictions, holding all variables in the model constant except the one plotted. Raw data shown as open circles (continuous) or boxplots (categorical). Upper $y$-axis limit set at $40 \%$ cover for ease of viewing the majority of data (55 high-cover data points not shown) of restoration at Hester Marsh (importance for each variable in parentheses, measured as percentage increase in MSE when the variable is randomly permuted; Electronic Supplement 1, Fig. S6): percent time inundated (32.8), post-restoration elevation (29.0), pre-restoration elevation (26.9), soil source (14.4), and tidal creek distance (4.3). The model with these five variables explained $25.4 \%$ of variance in the data. The site-wide vegetation cover model performed better without the remaining predictors: modeled salinity (Electronic Supplement 1, Fig. S11), soil addition or removal (Electronic Supplement 1, Fig. S16), habitat type prior to construction (Electronic Supplement 1, Fig. S15), and elevation change over the first year of restoration (Electronic Supplement 1, Fig. S13).

Inundation (\% time over the first 10 months of restoration), post-restoration elevation (2018), and pre-restoration elevation (2015) were the most important predictors of vegetation cover. Vegetation cover was predicted to be greatest in areas inundated approximately $0.85 \%$ of the time or less (Fig. 9a; Electronic Supplement 1, Fig. S10). Post-restoration elevation predicted a sharp increase in vegetation cover around $1.92 \mathrm{~m}$ (Fig. 9b; Electronic Supplement 1, Fig. S8). Cover was predicted to be lowest on former marsh plain elevations (1.2 to $3.0 \mathrm{~m}$ ) and greatest on scraped hillside areas that were above $3.3 \mathrm{~m}$ in elevation prior to construction of the restoration site (Fig. 9c; Electronic Supplement 1, Fig. S9). Vegetation cover was also predicted to be high in formerly low areas (below $1.2 \mathrm{~m}$ ). Soil source was moderately important, with more vegetation predicted on areas that received hillside soil rather than Pajaro River sediment (Fig. 9d; Electronic Supplement 1, Fig. S12). Tidal creek distance was only marginally important, with vegetation cover predicted to be greatest in areas farthest from creeks, though this was driven by only a few data points (Fig. 9e; Electronic Supplement 1, Fig. S14). 
While tidal creek distance did not clearly show greater vegetation cover in close proximity to creeks as a predictor in the site-wide UAS analysis, the pattern of high cover adjacent to creeks was visibly notable in the field and may be important on a smaller scale. Sloped creek banks also had very high cover, but we did not include these areas in the analysis due to an inability to accurately classify vegetation separately from the darker mud and algae present. We also observed some relatively bare swaths of marsh plain within four to $10 \mathrm{~m}$ of the existing vegetation that remained above the construction zone on some restoration site edges. Field observations indicated that many of these areas adjacent to existing vegetation were slightly sunken, leading to poor drainage and water pooling. Drone imagery and DSMs supported field observations of little new colonization and lower elevation in these areas near the site edges (Electronic Supplement 1, Fig. S7a-b).

\section{Soil Comparison at Well-Vegetated and Poorly-Vegetated Sites}

Well-vegetated sites had greater cover (estimated 10-50\% cover) and larger plants (average height $=13 \mathrm{~cm}$ ), in comparison to poorly-vegetated sites (estimated cover $<10 \%$, average height $=5 \mathrm{~cm}$ ). The 20 sites were at a mean elevation of $1.91 \pm 0.02 \mathrm{~m}$ and mean creek distance of $12.3 \pm 3.7 \mathrm{~m}$. As intended in the design of these paired comparisons, elevation and creek distance did not differ significantly between well-vegetated and poorly-vegetated sites.

There was significant separation between the 10 wellvegetated and 10 poorly-vegetated sites $(R=0.13, p=0.02$, ANOSIM), driven by a wide range of soil properties (Electronic Supplement 1, Table S1). SIMPER analysis revealed that poorly-vegetated sites were more similar to each other than well-vegetated sites (average squared distance $=15$ and 30, respectively; Electronic Supplement 1, Fig. S17). Poorlyvegetated sites had significantly greater soil ammonium levels, conductivity, and sodium and chloride concentrations compared to well-vegetated sites (Electronic Supplement 1, Table S1). We also used the soil sample data and fieldcollected conductivity/salinity data to further investigate the potential differences in Pajaro River dredge material and hillside material (Electronic Supplement 1).

\section{Discussion}

Overall, the multi-faceted approach we took, involving field surveys and UAS, and both random and targeted sampling, revealed key patterns and drivers of marsh colonization in the first year following restoration. We detected very low initial survival of pre-construction vegetation following soil addition, but relatively rapid and extensive colonization of new marsh plants. We found that various physical variables predict patterns of vegetation, particularly elevation and inundation time, and therefore recommend that these are particularly critical considerations for planning and monitoring of marsh restoration projects.

\section{Plant Survival Following Soil Addition}

While several studies of thin-layer sediment placement projects suggest that vegetation can survive sediment placement thicknesses of up to $20-30 \mathrm{~cm}$ (Reimold et al. 1978; Mendelssohn and Kuhn 2003; Frame et al. 2006), we observed little survival of pre-construction vegetation in the construction zone. Poor survival may be partially attributed to the thickness of soil added at Hester Marsh (on average, $69 \mathrm{~cm}$ in all soil addition areas and $37 \mathrm{~cm}$ on formerly vegetated areas) but is also likely due to the method of soil placement, because even areas with low levels of soil addition had few or no surviving plants. Thin-layer placement typically involves spraying or piping in sediment slurries (Slocum et al. 2005; Frame et al. 2006), while soil at Hester Marsh was placed by heavy construction equipment that drove over the marsh repeatedly. Future soil addition projects using earth-moving machinery should expect low survival of vegetation.

Somewhat surprisingly, most of the surviving vegetation at Hester Marsh was on former berms or areas within $5 \mathrm{~m}$ of those berms, where berm material was used for fill, suggesting that it likely grew from roots or other intact plant material that remained in upper layers of soil. Outside of the actively planted areas, these former berms and adjacent areas have the most native marsh species diversity; while Frankenia, Jaumea, and Distichlis survivors were fairly common in these areas, natural colonists of these species were rarely or never found during transect surveys.

\section{Temporal Trajectory of Early Colonization}

Past studies of bare sediment addition sites have revealed variable rates of colonization, from $0 \%$ cover after 1 year (La Peyre et al. 2009) to 77\% after 2.5 years (Mendelssohn and Kuhn 2003). We observed no new colonization by marsh species during the first eight months of the project (August 2018-April 2019). New seedlings began to emerge in early April 2019, and germination appeared to continue through June and July.

Overall vegetation cover was still relatively low in the initially bare construction area at the end of the first full growing season sampled: estimated vegetated cover was $13.6 \%$ based on August 2019 transect surveys, and 7.6\% based on October 2019 drone image classification. The discrepancy in estimates between the datasets may be due to the classified image underestimating cover (failing to capture small, 
sparse plants), seasonal dieback causing a true decline in green cover from the August field survey to the October UAS survey, or slight overestimation of cover in the transect dataset (possibly oversampling the high-elevation, scraped area with high vegetation cover). There was substantial variability in cover across the site (standard deviation of vegetated cover in initially bare quadrats $=24.3 \%$; Fig. 5). Native marsh species colonization captured during August 2019 transect surveys was dominated by Salicornia ( $99 \%$ of native marsh cover), with some representation of Spergularia sp. and Frankenia. Low diversity (Seabloom and van der Valk 2003; Armitage et al. 2006) and patchy colonization should be expected at future high marsh restoration sites, but results from vegetation monitoring and analysis at this site, such as environmental conditions associated with greater vegetation cover, can inform the design of future sites to optimize conditions for early colonization.

\section{Predictors of Plant Colonization}

Typically, salt marsh distribution and community structure are closely related to tidal inundation, which in turn is affected by elevation (Johnson and York 1915; Callaway et al. 1990; Janousek et al. 2019). In our study, the best predictors of vegetation cover overall were pre- and postrestoration elevation, salinity, and inundation. While the overall predictive power of models was low, possibly due to high stochasticity in seed deposition, both pre- and postrestoration elevation were important predictors in models of both transect and UAS vegetation cover data. Marsh vegetation cover was predicted to be greater at high elevation (above $1.92 \mathrm{~m}$ to $1.95 \mathrm{~m}$ ) and low inundation frequency (below $0.85 \%$ time inundated). Salinity was lowest in these high-elevation, infrequently inundated areas, indicating more favorable conditions for plant germination (Callaway et al. 1990; Shumway and Bertness 1992). This trend suggests that moisture did not limit vegetation establishment in high elevation areas, although rainfall was higher than average over the first year of restoration (19.6 inches, July 2018-June 2019; annual average of 16.0 inches since 2001; NOAA NERRS 2020). Different results would likely have been found under drought conditions (Chapple and Dronova 2017).

Relatively dense vegetation cover was also observed on the former hillside, which was grassland habitat above marsh elevation before soil was removed during construction. Soil "scraping" was favorable to marsh vegetation colonization, likely in part because these areas remained at higher elevation post-construction (Fig. 7a). Lower salinity in scraped compared with soil addition areas at the same elevation may also indicate favorable drainage, groundwater, or other soil conditions in scraped areas (Fig. 7c).
Other factors indicated greater vegetation colonization on the marsh plain near tidal creeks, which are commonly understood to influence marsh vegetation community structure (Zedler et al. 1999; Sanderson et al. 2001). While some studies have found reduced salinity near creeks (Balling and Resh 1983; Schile et al. 2011) and improved Salicornia growth under reduced salinity (height, Schile et al. 2011; shoot growth, Mahall and Park 1976b), areas adjacent to creeks at Hester Marsh do not appear to have lower salinity (Krause 2020). There are several possible explanations for greater vegetation cover in these areas, despite their greater salinity, relating to either pre- or post-settlement processes. These might include greater seed deposition (Hopkins and Parker 1984), improved drainage (Schile et al. 2011; Chapple and Dronova 2017) or increased moisture (Noe and Zedler 2000) ameliorating salinity stress, lower sulfide accumulations (King et al. 1982), or nutrient subsidies from fish and invertebrates (Allen et al. 2013). Frequently inundated areas near tidal creeks may also have faster development of the soil microbial community, which can be a precursor to vegetation development (Lynum et al. 2020).

Soil properties are an important consideration in marsh restoration (Broome 1989), with potential effects on pore water nutrients, salinity, and pH (Wigand et al. 2016). Better understanding of these factors can inform selection of source material for soil and sediment addition projects and adaptive management to mitigate plant stressors. Soil analysis at Hester Marsh indicated greater salinity and ammonium levels at poorly-vegetated compared to well-vegetated sites. Future studies should examine strategies to mitigate salinity stress at soil/sediment addition sites, particularly in areas away from tidal creeks. However, the low explanatory power of salinity on its own suggests that vegetation colonization may be influenced by seed deposition and germination limitations other than salinity stress. Soil sampling can examine additional potential abiotic and biotic limitations of vegetation colonization, such as soil compaction (as an indicator of porosity/permeability), hydrogen sulfide concentrations, or development of the soil microbial community. While we do not believe seeds are limited in the tidal waters at this site due to the proximity of healthy pickleweed marshes and strong tidal currents, further studies can also examine variability in seed deposition on the marsh plain.

\section{Comparison of Monitoring Methodologies}

Monitoring of vegetation development is critical to marsh restoration projects (Zedler 2000; Williams and Faber 2001), particularly for understanding and evaluating relatively novel approaches like soil/sediment addition (Mendelssohn and Kuhn 2003). With recently introduced technologies 
like high-resolution remote sensing by UAS in restoration monitoring (Knoth et al. 2013; Buters et al. 2019; Haskins et al. 2021), there is not yet consensus on the most effective approach for tracking vegetation cover, monitoring physical variables related to vegetation, and modeling the drivers of vegetation patterns. We have some recommendations based on our comparison of multiple approaches.

For monitoring plant colonization, field- and UAS-based approaches yielded similar estimates of overall vegetation cover at the end of year one. We found field methods more advantageous for distinguishing between species in cover assessments, which enabled us to evaluate the upper marsh boundary in relation to tide data (Electronic Supplement 1, Characterization of Inundation Across Elevations). While other studies find UAS more efficient in time and effort spent compared with field methods (Chabot and Bird 2013), this advantage was not as apparent at this moderately sized site; we surveyed 280 quadrats in one day with a team of four people, but it is acknowledged that vegetation cover was sparse during this early stage of restoration. Another general advantage of UAS monitoring is the ability to cover an entire site, while field methods are limited by walking access. Similarities in transect and UAS modeling results indicate that limitations in transect survey coverage did not impact our understanding of the predictors of vegetation cover. Although transect monitoring was suitable at our site, UAS was a very useful complement, and may provide more substantial benefits over field methods at larger or less accessible sites.

To quantify critical explanatory variables, we recommend focusing on elevation, given its high importance in both modeling approaches. Field measurements with laser leveling from benchmarks as well as DSMs created from UAS linked to ground control points both yielded accurate elevation profiles. Inundation frequency was an important factor in controlling plant colonization, which we calculated fairly easily using water level data from a nearby sonde of known elevation. Inundation frequency predicted more variation than salinity estimates in our UAS analysis, and elevation outperformed salinity in both transect and UAS analyses, suggesting that salinity data modeled across the entire site were not sufficiently accurate to predict vegetation. Given the relative difficulty of obtaining salinity data, and lower explanatory power of this variable, we recommend focusing on elevation and inundation frequency, at least in very marine-influenced marshes such as this one.

Large-scale restoration projects provide a remarkable opportunity for learning about mechanisms, and investing in rigorous monitoring informs future projects and enhances their success (Zedler 2000; Boyer and Thornton 2012). Our investigation serves as a model for other salt marsh restoration projects by integrating data on elevation, inundation, soil properties, and vegetation from both field sampling and remote sensing, and incorporating all of these into predictive models. The multi-faceted monitoring and modeling approach we implemented proved powerful in characterizing patterns of colonization as well as elucidating the potential mechanisms behind the observed patterns, and will inform future marsh restoration in California and beyond.

Supplementary Information The online version contains supplementary material available at https://doi.org/10.1007/s12237-021-00977-4.

Acknowledgements We would like to thank the following individuals for contributions to this work: A. Lapides, Dr. R. Jeppesen, Dr. I. Aiello, Dr. F. Watson, Dr. J. Olson, R. Kwan-Davis, J. Mejia-Muñoz, and J. Bennett. We are also deeply grateful for the support of Dr. A. Haffa for advising A. Thomsen's Master's thesis, from which this manuscript was adapted, and Dr. S. Worcester for guidance as a thesis committee member. We would also like to thank Dr. C. Garza and Dr. L. Good for advising and supporting A. Thomsen as a National Oceanic and Atmospheric Administration Center for Coastal and Marine Ecosystems Graduate Fellow at California State University Monterey Bay. We thank editor C. Roman and two anonymous reviewers for improving the clarity and structure of this paper.

Funding Funding of Elkhorn Slough National Estuarine Research Reserve (ESNERR) staff was provided by a grant from the National Oceanic and Atmospheric Administration Office for Coastal Management. The Hester Marsh restoration project was coordinated by ESNERR's Tidal Wetland Program and funded by grants from California Department of Water Resources, California Department of Fish and Wildlife, California Coastal Conservancy, U.S. Fish and Wildlife Service National Coastal Wetlands Conservation Grant Program, Ocean Protection Council, and the Wildlife Conservation Board to the Elkhorn Slough Foundation on behalf of ESNERR. This publication was made possible by the National Oceanic and Atmospheric Administration, Office of Education Educational Partnership Program award (NA16SEC4810009). Its contents are solely the responsibility of the award recipient and do not necessarily represent the official views of the US Department of Commerce, National Oceanic and Atmospheric Administration.

Open Access This article is licensed under a Creative Commons Attribution 4.0 International License, which permits use, sharing, adaptation, distribution and reproduction in any medium or format, as long as you give appropriate credit to the original author(s) and the source, provide a link to the Creative Commons licence, and indicate if changes were made. The images or other third party material in this article are included in the article's Creative Commons licence, unless indicated otherwise in a credit line to the material. If material is not included in the article's Creative Commons licence and your intended use is not permitted by statutory regulation or exceeds the permitted use, you will need to obtain permission directly from the copyright holder. To view a copy of this licence, visit http://creativecommons.org/licenses/by/4.0/.

\section{References}

Allen, D.M., S.A. Luthy, J.A. Garwood, R.F. Young, and R.F. Dame. 2013. Nutrient subsidies from nekton in salt marsh intertidal creeks. Limnology and Oceanography 58: 1048-1060.

Anderson, K., and K.J. Gaston. 2013. Lightweight unmanned aerial vehicles will revolutionize spatial ecology. Frontiers in Ecology and the Environment 11: 138-146. 
Armitage, A.R., K.E. Boyer, R.R. Vance, and R.F. Ambrose. 2006. Restoring assemblages of salt marsh halophytes in the presence of a rapidly colonizing dominant species. Wetlands 26 (3): 667-676.

Balling, S.S., and V.H. Resh. 1983. The influence of mosquito control recirculation ditches on plant biomass, production and composition in two San Francisco Bay salt marshes. Estuarine, Coastal and Shelf Science 16 (2): 151-161.

Barbier, E.B., S.D. Hacker, C. Kennedy, E.W. Koch, A.C. Stier, and B.R. Silliman. 2011. The value of estuarine and coastal ecosystem services. Ecological Monographs 81: 169-193.

Boyer, K.E., and W.J. Thornton. 2012. Natural and restored tidal marsh communities. In and Restoration of Tidal Marshes, ed. Conservation Ecology, 233-252. Berkeley, CA, USA: University of California Press.

Broome, S.W. 1989. Creation and restoration of tidal wetlands of the southeastern United States. In Wetland Creation and Restoration: The status of the science, Vol. I, ed. J.A. Kusler and M.E. Kentula, 37-72. Corvallis, OR, USA: United States Environmental Protection Agency.

Buters, T.M., P.W. Bateman, T. Robinson, D. Belton, K.W. Dixon, and A.T. Cross. 2019. Methodological ambiguity and inconsistency constrain unmanned aerial vehicles as a silver bullet for monitoring ecological restoration. Remote Sensing 11 (1180): 1-16.

Caffrey, J.M., M. Brown, W.B. Tyler, and M. Silberstein, editors. 2002. Changes in a California estuary: A profile of Elkhorn Slough. Moss Landing, CA, USA: Elkhorn Slough Foundation. http:// library.elkhornslough.org/attachments/Caffrey_2002_Changes_ In_A_California.pdf. Accessed 9 March 2021.

Cahoon, D.R., J.C. Lynch, C.T. Roman, J.P. Schmit, and D.E. Skidds. 2019. Evaluating the relationship among wetland vertical development, elevation capital, sea-level rise, and Tidal marsh sustainability. Estuaries and Coasts 42: 1-15.

Callaway, J.C., V.T. Parker, M.C. Vasey, L.M. Schile, and E.R. Herbert. 2011. Tidal wetland restoration in San Francisco Bay: History and current issues. San Francisco Estuary and Watershed Science 9 (3): 1-12.

Callaway, R.M., S. Jones, W.R. Ferren, and A. Parikh. 1990. Ecology of a mediterranean-climate estuarine wetland at Carpinteria, California; plant distributions and soil salinity in the upper marsh. Canadian Journal of Botany 68: 1139-1146.

Chabot, D., and D.M. Bird. 2013. Small unmanned aircraft: Precise and convenient new tools for surveying wetlands. Journal of Unmanned Vehicle Systems 1: 15-24.

Chabot, D., and D.M. Bird. 2015. Wildlife research and management methods in the 21st century: Where do unmanned aircraft fit in? Journal of Unmanned Vehicle Systems 3: 137-155.

Chapple, D., and I. Dronova. 2017. Vegetation development in a tidal marsh restoration project during a historic drought: A remote sensing approach. Frontiers in Marine Science 4.

Clarke, D.W., J.F. Boyle, J. Lario, and A.J. Plater. 2014a. Meso-scale barrier estuary disturbance, response and recovery behaviour: Evidence of system equilibrium and resilience from high-resolution particle size analysis. The Holocene 24 (3): 357-369.

Clarke, K.R., R.N. Gorley, P.J. Somerfield, and R.M. Warwick. 2014b. Change in marine communities: An approach to statistical analysis and interpretation, 3rd ed. Plymouth, UK: Primer-E.

Cutler, D.R., T.C. Edwards, K.H. Beard, A. Cutler, K.T. Hess, J. Gibson, and J.J. Lawler. 2007. Random forests for classification in ecology. Ecology 88 (11): 2783-2792.

Deegan, L.A., D.S. Johnson, R.S. Warren, B.J. Peterson, J.W. Fleeger, S. Fagherazzi, and W.M. Wollheim. 2012. Coastal eutrophication as a driver of salt marsh loss. Nature 490 (7420): 388-392.

[ESRI] Environmental Systems Research Institute. 2019. ArcGIS Desktop. Version 10.7. Redlands, CA, USA: Environmental Systems Research Institute, Inc.
Fountain, M., C. Jeppesen, C. Endris, A. Woolfolk, E. Watson, I. Aiello, S. Fork, J. Haskins, K. Beheshti, and K. Wasson. 2019. Hester Marsh restoration: Annual report. Elkhorn Slough National Estuarine Research Reserve. https://www.elkhornslough.org/tidalwetland-program/. Accessed 20 July 2020.

Frame, G.W., M.K. Mellander, and D.A. Adamo. 2006. Big Egg marsh experimental restoration in Jamaica Bay, New York. In People, Places, and Parks: Proceedings of the 2005 George Wright Society Conference on Parks, Protected Areas, and Cultural Sites, ed. D. Harmon, 123-130. Hancock, MI, USA: The George Wright Society.

Gray, P.C., J.T. Ridge, S.K. Poulin, A.C. Seymour, A.M. Schwantes, J.J. Swenson, and D.W. Johnston. 2018. Integrating drone imagery into high resolution satellite remote sensing assessments of estuarine environments. Remote Sensing 10 (8): 1257.

Haskins, J., C. Endris, A.S. Thomsen, F. Gerbl, M.C. Fountain, and K. Wasson. 2021. UAV to inform restoration: A case study from a California tidal marsh. Frontiers in Environmental Science 9 (642906): 1-20.

Hopkins, D.R., and V.T. Parker. 1984. A study of the seed bank of a salt marsh in northern San Francisco Bay. American Journal of Botany 71 (3): 348-355.

Huiskes, A.H.L., B.P. Koutstaal, P.M.J. Herman, W.G. Beeftink, M.M. Markusse, and W. De Munck. 1995. Seed Dispersal of Halophytes in Tidal Salt Marshes. Journal of Ecology 83 (4): 559-567.

Janousek, C.N., K.M. Thorne, and J.Y. Takekawa. 2019. Vertical Zonation and Niche Breadth of Tidal Marsh Plants Along the Northeast Pacific Coast. Estuaries and Coasts 42: 85-98.

Johnson, D.S., and H.H. York. 1915. The relation of plants to tidelevels: A study of factors affecting the distribution of marine plants, 5-112. Washington, D.C., USA: The Carnegie Institution of Washington.

Kennish, M.J. 2001. Coastal salt marsh systems in the U.S.: A review of anthropogenic impacts. Journal of Coastal Research 17(3): 731-748.

King, G.M., M.J. Klug, R.G. Wiegert, and A.G. Chalmers. 1982. Relation of soil water movement and sulfide concentration to Spartina alterniflora production in a Georgia salt marsh. Science 218 (4567): 61-63.

Kirwan, M.L., and J.P. Megonigal. 2013. Tidal wetland stability in the face of human impacts and sea-level rise. Nature 504: 53-60.

Knoth, C., B. Klein, T. Prinz, and T. Kleinebecker. 2013. Unmanned aerial vehicles as innovative remote sensing platforms for highresolution infrared imagery to support restoration monitoring in cut-over bogs. Applied Vegetation Science 16 (3): 509-517.

Krause, J. 2020. Hester Marsh Salinity Report. Elkhorn Slough Technical Report Series 2020:1. http://www.elkhornslough.org/resea rch-program/technical-report-series/. Accessed 20 July 202020.

La Peyre, M.K., B. Gossman, and B.P. Piazza. 2009. Short- and longterm response of deteriorating brackish marshes and open-water ponds to sediment enhancement by thin-layer dredge disposal. Estuaries and Coasts 32: 390-402.

Larson, E. 2001. Coastal wetlands - emergent marshes. In California's living marine resources: A status report, 483-486.

Li, X., R. Bellerby, C. Craft, and S.E. Widney. 2018. Coastal wetland loss, consequences, and challenges for restoration. Anthropocene Coasts 1: 1-15.

Liaw, A., and M. Wiener. 2002. Classification and regression by randomForest. $R$ News 2 (3): 18-22.

Lynum, C.A., A.N. Bulseco, C.M. Dunphy, S.M. Osborne, J.H. Vineis, and J.L. Bowen. 2020. Microbial community response to a passive salt marsh restoration. Estuaries and Coasts 43: 1439-1455.

Mahall, B.E., and R.B. Park. 1976a. The ecotone between Spartina foliosa Trin. and Salicornia virginica $L$. in salt marshes of northern San Francisco Bay: I. Biomass and production. The Journal of Ecology 64(2):421-433. 
Mahall, B.E., and R.B. Park. 1976b. The ecotone between Spartina foliosa Trin. and Salicornia virginica L. in salt marshes of northern San Francisco Bay: II. Soil water and salinity. The Journal of Ecology 64(3):793-809.

Mahall, B.E., and R.B. Park. 1976c. The ecotone between Spartina foliosa Trin. and Salicornia virginica L. in salt marshes of northern San Francisco Bay: III. Soil aeration and tidal immersion. The Journal of Ecology 64(3):811-819.

Mayer, M.A. 1987. Flowering plant recruitment into a newly restored salt marsh in Elkhorn Slough, California. Moss Landing Marine Laboratories.

Mendelssohn, I.A., and N.L. Kuhn. 2003. Sediment subsidy: Effects on soil-plant responses in a rapidly submerging coastal salt marsh. Ecological Engineering 21: 115-128.

Mitsch, W.J., B. Bernal, and M.E. Hernandez. 2015. Ecosystem services of wetlands. International Journal of Biodiversity Science, Ecosystem Services and Management 11: 1-4.

Morzaria-Luna, H.N., and J.B. Zedler. 2007. Does seed availability limit plant establishment during salt marsh restoration? Estuaries and Coasts 30 (1): 12-25.

National Lacustrine Core Facility. Loss-on-ignition standard operating procedure. 2013. LacCore, National Lacustrine Core Facility. http://lrc.geo.umn.edu/laccore/assets/pdf/sops/loi.pdf. Accessed 20 July 2020.

[NOAA NERRS] National Oceanic and Atmospheric Administration National Estuarine Research Reserve System. 2020. System-wide Monitoring Program. http://www.nerrsdata.org. Accessed $15 \mathrm{Sept}$ 2020.

Noe, G.B., and J.B. Zedler. 2000. Differential effects of four abiotic factors on the germination of salt marsh annuals. American Journal of Botany 87 (11): 1679-1692.

Noe, G.B., and J.B. Zedler. 2001. Spatio-temporal variation of salt marsh seedling establishment in relation to the abiotic and biotic environment. Journal of Vegetation Science 12: 61-74.

[NYDOT] State of New York Department of Transportation. Geotechnical Test Method: Test Method for Liquid Limit, Plastic Limit, and Plasticity Index. GTM-7 Revision \#2. 2015. State of New York Department of Transportation, Geotechnical Engineering Bureau. https://www.dot.ny.gov/divisions/engineering/ technical-services/technical-services-repository/GTM-7b.pdf. Accessed 20 July 2020

R Core Team. 2018. R: A language and environment for statistical computing. Version 3.5.1. Vienna, Austria: R Foundation for Statistical Computing. https://www.R-project.org/.

Raposa, K.B., K. Wasson, J. Nelson, M. Fountain, J. West, C. Endris, and A. Woolfolk. 2020. Guidance for thin-layer sediment placement as a strategy to enhance tidal marsh resilience to sea-level rise. Published in collaboration with the National Estuarine Research Reserve System Science Collaborative. www.nerra.org/ reserves/science-tools/tlp. Accessed 8 July 2020.

Reimold, R.J., M.A. Hardisky, and P.C. Adams. 1978. The effects of smothering a Spartina alterniflora salt marsh with dredged material. Technical report D-78-38.

Sanderson, E.W., T.C. Foin, and S.L. Ustin. 2001. A simple empirical model of salt marsh plant spatial distributions with respect to a tidal channel network. Ecological Modelling 139: 293-307.

Schile, L.M., J.C. Callaway, V.T. Parker, and M.C. Vasey. 2011. Salinity and inundation influence productivity of the halophytic plant Sarcocornia pacifica. Wetlands 31: 1165-1174.
Seabloom, E.W., and A.G. van der Valk. 2003. Plant diversity, composition, and invasion of restored and natural prairie pothole wetlands: Implications for restoration. Wetlands 23 (1): 1-12.

Shuman, C.S., and R.F. Ambrose. 2003. A comparison of remote sensing and ground-based methods for monitoring wetland restoration success. Restoration Ecology 11 (3): 325-333.

Shumway, S.W., and M.D. Bertness. 1992. Salt stress limitation of seedling recruitment in a salt marsh plant community. Oecologia 92: 490-497.

Slocum, M.G., I.A. Mendelssohn, and N.L. Kuhn. 2005. Effects of sediment slurry enrichment on salt marsh rehabilitation: Plant and soil responses over seven years. Estuaries 28 (4): 519-528.

Stagg, C.L., and I.A. Mendelssohn. 2010. Restoring ecological function to a submerged salt marsh. Restoration Ecology 18 (SUPPL. 1): 10-17.

Tuxen, K.A., L.M. Schile, M. Kelly, and S.W. Siegel. 2008. Vegetation colonization in a restoring tidal marsh: A remote sensing approach. Restoration Ecology 16 (2): 313-323.

Van Dyke, E., and K. Wasson. 2005. Historical Ecology of a Central California Estuary: 150 Years of Habitat Change. Estuaries 28 (2): 173-189.

Walters, D.C., and M.L. Kirwan. 2016. Optimal hurricane overwash thickness for maximizing marsh resilience to sea level rise. Ecology and Evolution 6 (9): 2948-2956.

Wasson, K., R. Jeppesen, C. Endris, D.C. Perry, A. Woolfolk, K. Beheshti, M. Rodriguez, et al. 2017. Eutrophication decreases salt marsh resilience through proliferation of algal mats. Biological Conservation 212: 1-11.

Wasson, K., E.B. Watson, E. Van Dyke, G. Hayes, and I. Aiello. 2012. A novel approach combining rapid paleoecological assessments with geospatial modeling and visualization to help coastal managers design salt marsh conservation strategies in the face of environmental change. Elkhorn Slough Technical Report Series 2012:1. http://www.elkhornslough.org/research-program/technical-reportseries/. Accessed 23 July 2020.

Watson, E.B., C. Wigand, E.W. Davey, H.M. Andrews, J. Bishop, and K.B. Raposa. 2017. Wetland loss patterns and inundation-productivity relationships prognosticate widespread salt marsh loss for southern New England. Estuaries and Coasts 40 (3): 662-681.

Weston, N.B. 2014. Declining sediments and rising seas: An unfortunate convergence for tidal wetlands. Estuaries and Coasts 37 (1): 1-23.

Wigand, C., K. Sundberg, A. Hanson, E. Davey, R. Johnson, E. Watson, and J. Morris. 2016. Varying inundation regimes differentially affect natural and sand-amended marsh sediments. PLOS ONE 11(10).

Williams, P., and P. Faber. 2001. Salt marsh restoration experience in San Francisco Bay. Journal of Coastal Research S I (27): 203-211.

Woo, I., and J.Y. Takekawa. 2012. Will inundation and salinity levels associated with projected sea level rise reduce the survival, growth, and reproductive capacity of Sarcocornia pacifica (pickleweed)? Aquatic Botany 102: 8-14.

Zedler, J.B. 2000. Progress in wetland restoration ecology. Trends in Ecology and Evolution 15 (10): 402-407.

Zedler, J.B., J.C. Callaway, J.S. Desmond, G. Vivian-Smith, G.D. Williams, G. Sullivan, A.E. Brewster, and B.K. Bradshaw. 1999. Californian salt-marsh vegetation: An improved model of spatial pattern. Ecosystems 2: 19-35. 